(n)

\title{
Immunological role of vitamin D at the maternal-fetal interface
}

\author{
J A Tamblyn ${ }^{1,2}$, M Hewison ${ }^{2}$, C L Wagner ${ }^{3}$, J N Bulmer ${ }^{4}$ and M D Kilby ${ }^{1,2,5}$ \\ ${ }^{1}$ College of Medical and Dental Sciences, Centre for Women's and Children's Health, and ${ }^{2}$ College of Medical and \\ Dental Sciences, Centre of Endocrinology, Diabetes and Metabolism (CEDAM), University of Birmingham, \\ Edgbaston, Birmingham B15 2TT, UK \\ ${ }^{3}$ Departments of Pediatrics, Biochemistry, and Molecular Biology, Medical University of South Carolina, Charleston, \\ South Carolina 29425, USA \\ ${ }^{4}$ Reproductive and Vascular Biology Group, Institute of Cellular Medicine, Newcastle University, Newcastle upon \\ Tyne NE2 4HH, UK \\ ${ }^{5}$ Fetal Medicine Centre, Birmingham Women's Foundation Trust, Birmingham B15 2TG, UK
}

\author{
Correspondence \\ should be addressed \\ to J A Tamblyn \\ Email \\ j.tamblyn@bham.ac.uk
}

\begin{abstract}
During pregnancy, immune activity is tightly regulated so that antimicrobial protection of the mother and fetus is balanced with the need for immune tolerance to prevent fetal rejection. In this setting, the maternal-fetal interface, in the form of the uterine decidua, provides a heterogeneous immune cell population with the potential to mediate diverse activities throughout pregnancy. Recent studies have suggested that vitamin D may be a key regulator of immune function during pregnancy, with the fetal-maternal interface representing a prominent target. Among its non-classical actions are potent immunomodulatory effects, including induction of antibacterial responses and modulation of T-lymphocytes to suppress inflammation and promote tolerogenesis. Thus, vitamin D may play a pivotal role in normal decidual immune function by promoting innate responses to infection, while simultaneously preventing an over-elaboration of inflammatory adaptive immunity. Research to date has focused upon the potential role of vitamin $D$ in preventing infectious diseases such as tuberculosis, as well as possibly suppressing of autoimmune disease. Nevertheless, vitamin D may also influence facets of immune function not immediately associated with primary innate responses. This review summarises our current understanding of decidual immune function with respect to the vitamin D metabolism and signalling, and as to how this may be affected by variations in maternal vitamin $D$ status. There has recently been much interest in vitamin D supplementation of pregnant women, but our knowledge of how this may influence the function of decidua remains limited. Further insight into the immunomodulatory actions of vitamin D during pregnancy will help shed light upon this.
\end{abstract}

\author{
Key Words \\ - vitamin D \\ - decidua \\ - fetal-maternal interface \\ - immunity \\ - monocyte \\ - T cell \\ - uterine natural killer cell
}

\section{Introduction}

\section{Immune function in pregnancy}

From initial implantation of the conceptus, the maternal uterine endometrium undergoes 'decidualisation' to support placental development and function. The resulting decidua is a tissue formed from the maternal endometrium, originating from epithelial and stromal cells, and is characterised by invasion from the extraembryonic fetal-derived trophoblasts and close 'cell-cell 
juxtaposition' of these different tissues (Fig. 1). The principal function of the decidua is to facilitate early fetal-maternal exchange of nutrients, gases and waste, while also acting as a secretory source of an array of steroid hormones, cytokines and growth factors (Gellersen et al. 2007, Salamonsen et al. 2007, Ramathal et al. 2010). However, the decidua also plays a key role in protecting pregnancy against maternal immune surveillance (Warning et al. 2011), and this feature will be the focus of the current review.
Pregnancy presents a unique immune challenge for the maternal host. Systemically, significant gestationdependent immune adaptions arise throughout pregnancy and characterisation of these is a major focus of materno-fetal immunology research (Moffett \& Loke 2006). Specifically, in the mother, there is a shift towards immune tolerance to accommodate the conceptus (Alijotas-Reig et al. 2014). As a result, the maternal-fetal interface is a prime area of immune regulation, and cellular immunity within the decidua is importantly

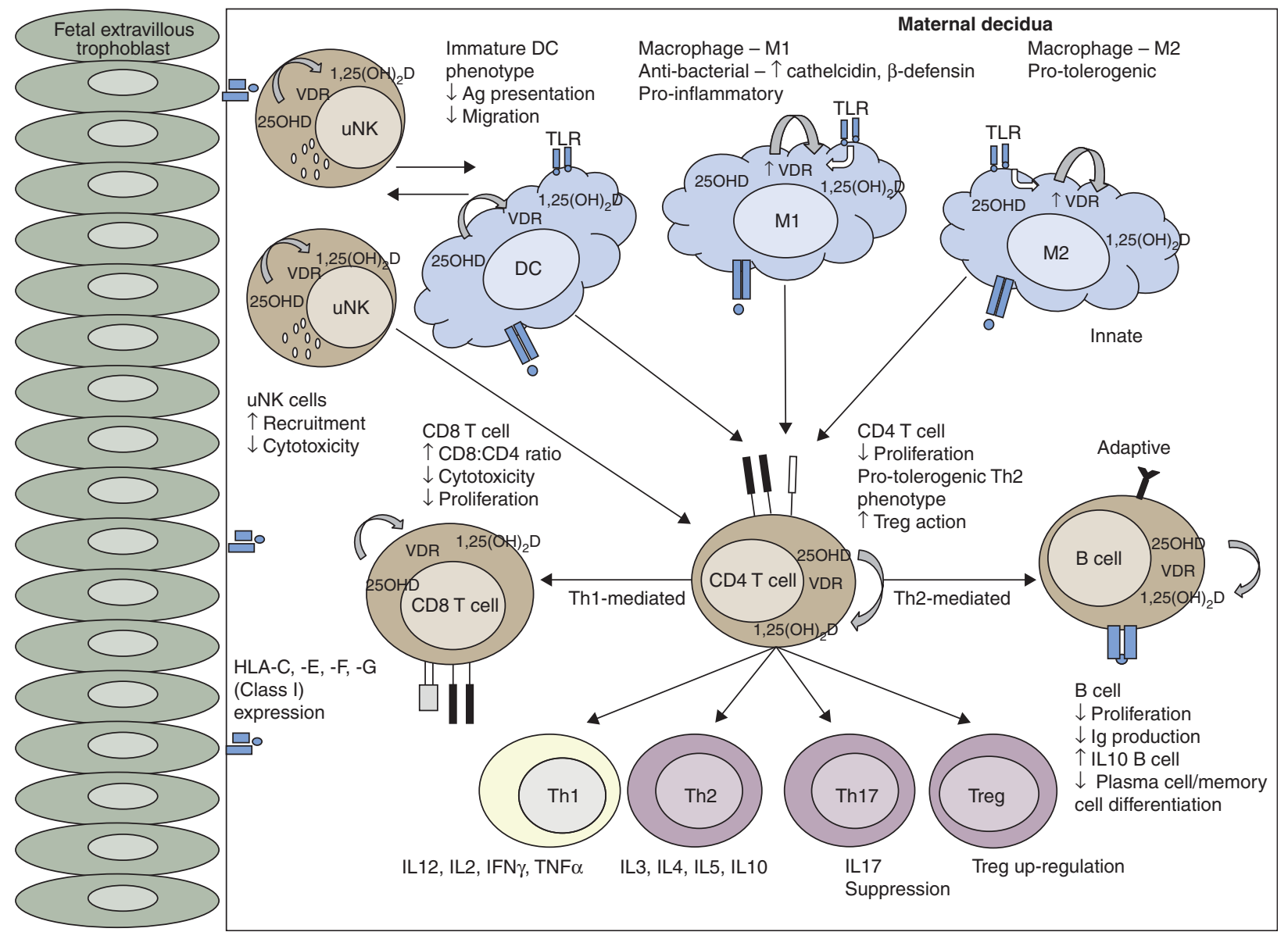

\section{Figure 1}

Proposed immunomodulatory effects of vitamin D at the maternal-fetal interface. Illustration of both the innate and adaptive leukocyte decidual subsets with the potential capacity for intrinsic 1,25-dihydroxyvitamin $D$ $\left(1,25(\mathrm{OH})_{2} \mathrm{D}\right)$ synthesis from 25 -hydroxyvitamin $\mathrm{D}$ (25OHD), including uterine NK cells (uNK), macrophages, dendritic cells (DCs), T cells and B cells. Their postulated pro-tolerogenic effects specifically at the fetal-maternal interface, in the presence of $1,25(\mathrm{OH})_{2} \mathrm{D}$, are illustrated. Notably, uNK cells predominate and demonstrate reduced cytotoxic potential. 'M1' macrophage subtypes exist, demonstrating enhanced antibacterial, pro-inflammatory actions in the presence of $1,25(\mathrm{OH})_{2} \mathrm{D}$. However, the protolerogenic 'M2' subsets predominate, displaying both enhanced proliferative and tissue remodelling capacities. Immature DCs are sparse; $1,25(\mathrm{OH})_{2} \mathrm{D}$ may augment their reduced capacity for antigen presentation and enhanced expression of anti-inflammatory cytokines, such as IL10. Immunosuppressive $\mathrm{CD}^{+}$and $\mathrm{CD}^{+}{ }^{+} \mathrm{T}$ cells coexist and they are suspected key producers of $1,25(\mathrm{OH})_{2} \mathrm{D}$. Postulated pro-tolerogenic effects include $a$ shift from a Th1 to a Th2 phenotype, increased T regulatory cell (Treg) production and suppression of T helper 17 cell (Th17) activity. Finally, albeit infrequent in number, $\mathrm{B}$ cell proliferation and differentiation may be inhibited in the presence of $1,25(\mathrm{OH})_{2} \mathrm{D} .1,25 \mathrm{D}, 1,25(\mathrm{OH})_{2} \mathrm{D} ; 25 \mathrm{D}, 25 \mathrm{OHD}$; $M$, macrophage; DC, dendritic cell; HLA, human leukocyte antigen; Ig, immunoglobulin; IL, interleukin; 25OHD, 25-hydroxyvitamin D; $1,25(\mathrm{OH})_{2} \mathrm{D}, 1,25$-dihydroxyvitamin $\mathrm{D}$; VDR, vitamin D receptor; uNK, uterine natural killer cell; Th, T helper cell; Treg, T Regulatory cell; $\mathrm{CD}$, cluster of differentiation; $\mathrm{Ag}$, antigen; IFN $\gamma$, interferon gamma; $\mathrm{TNF} \alpha$, tumour necrosis factor alpha. 
different from that within the maternal circulation. Cellular infiltration is a key feature of immune function within decidua, and leukocytes comprise at least $40 \%$ of the total decidual stromal cell population (Bulmer et al. $1988,1991)$. The leukocyte subtypes present include decidual (uterine) natural killer (uNK) cells, macrophage subtypes, $\mathrm{CD}^{+}$and $\mathrm{CD} 8^{+}$T-lymphocytes (including T-regulatory cells (Tregs)) and antigen-presenting cells (APCs) such as dendritic cells (DCs) (Arck \& Hecher 2013). Although well classified anatomically, these immune cells and, in particular, their function are the focus of much contemporary research. There has been renewed interest in the role of hormones as key regulators of decidual immune cell function (Oreshkova et al. 2012). The current review will focus on one of these hormones, vitamin $\mathrm{D}$, and its possible roles in fetal-maternal immune tolerance, and the prevention of adverse events in pregnancy.

\section{Vitamin $D$ and human pregnancy}

Vitamin D is a secosteroid classically recognised for its key role in bone metabolism and calcium homoeostasis. Since the 1980s, many important 'non-classical' extra-skeletal functions of vitamin D have been described, including anti-proliferative, pro-differentiative and potent immunomodulatory actions (Haussler et al. 2008). A central feature of these extra-skeletal actions is the recognition that they probably involve autocrine/intracrine metabolic mechanisms that are distinct from the 'classical' endocrine renal generation of active 1,25-dihydroxyvitamin D $\left(1,25(\mathrm{OH})_{2} \mathrm{D}\right)$ characteristic of skeletal actions of vitamin D. Specifically, many non-classical actions of vitamin D are associated with localised metabolism of precursor 25-hydroxyvitamin D (25OHD), with the resulting active $1,25(\mathrm{OH})_{2} \mathrm{D}$ signalling via endogenous vitamin $\mathrm{D}$ receptors (VDRs) (Hewison et al. 2007, Hewison 2010). While intracrine synthesis of $1,25(\mathrm{OH})_{2} \mathrm{D}$ provides many advantages for tissue-specific regulation of vitamin D function, it is also likely to be more sensitive to variations in concentrations of the substrate 25OHD. As 25OHD is the principal marker of vitamin $\mathrm{D}$ 'status' in any given individual, this has raised the question as to how vitamin D sufficiency or deficiency may affect tissues in which there is significant metabolism of 25OHD. Prominent among these tissues is the placenta, where both fetal and maternal tissues have been shown to synthesise 'active' 1,25(OH) $)_{2} \mathrm{D}$ (Gray et al. 1979, Weisman et al. 1979).

The implications of vitamin D deficiency are far reaching. Classically, severe vitamin D deficiency is recognised for its negative effect on bone mineralisation, as manifested by rickets in children and osteomalacia in adults (Holick 2007, Holick \& Chen 2008). In more recent studies, low serum levels of 25OHD have been associated with common cancers, allergic disorders, infections, autoimmune disorders and cardiovascular disease (Hypponen et al. 2001, Cannell et al. 2006, Munger et al. 2006, Grant \& Mohr 2009, Brehm et al. 2010, Zittermann et al. 2011). However, the questions as to what constitutes optimal or adequate vitamin D status and what is the magnitude of vitamin D-deficiency in populations across the globe are a subject of debate (Holick 2007). The 14th Workshop Consensus on Vitamin D concluded that a global vitamin D deficiency epidemic exists (defined by a serum $25 \mathrm{OHD}$ below $12 \mathrm{ng} / \mathrm{ml}$ or $30 \mathrm{nM}$ ) and represents a major health problem (Henry et al. 2010). By contrast, the current Institute of Medicine (IOM) classification of vitamin status is as follows: deficiency as $25 \mathrm{OHD}<20 \mathrm{ng} / \mathrm{ml}(50 \mathrm{nM})$, and vitamin D insufficiency as $25 \mathrm{OHD}<30 \mathrm{ng} / \mathrm{ml}$ (75 nM) (Holick et al. 2011). In 2010, the IOM recommended an increase in the minimal daily intake of vitamin $\mathrm{D}$ too by at least $600 \mathrm{IU}(600 \mathrm{IU}=15 \mu \mathrm{g}) /$ day, and they also recognised that at least 1500-2000 IU/day of vitamin $\mathrm{D}$ may be needed to maintain a blood level of $25 \mathrm{OHD}>30 \mathrm{ng} / \mathrm{ml}$, with a maximum upper level of $4000 \mathrm{IU} /$ day for adults, including pregnant women (Holick et al. 2011).

One group who appear to be at particular risk of vitamin D deficiency are pregnant women and women breastfeeding for long periods (Holick 2007, Mithal et al. 2009); with those living at high latitude with reduced sunlight exposure, dark skin pigmentation, or with a high BMI, and poor dietary intake at the greatest risk of low vitamin D status (Mithal et al. 2009, Holick et al. 2011). At present, no separate consensus regarding optimum vitamin D levels in pregnancy has been reached and general IOM standard cutoff values are currently in use. In 2006, $7 \%$ of pregnant or lactating women in a large national database in the USA were reported as being vitamin $\mathrm{D}$ deficient $(<30 \mathrm{nM}(<12 \mathrm{ng} / \mathrm{ml})$ serum $25 \mathrm{OHD})$, and $28 \%$ as vitamin D 'inadequate' $(<50 \mathrm{nM}(<20 \mathrm{ng} / \mathrm{ml})$ serum 25OHD) (Looker et al. 2011). In other studies, Bodnar et al. (2007a) showed that $83 \%$ of pregnant US black women and $47 \%$ of pregnant white women were vitamin D insufficient ( $<32 \mathrm{ng} / \mathrm{ml}$ serum $25 \mathrm{OHD}$ ) at delivery, with similar values for neonates. Prevalence rates for vitamin $\mathrm{D}$ deficiency ( $<20 \mathrm{ng} / \mathrm{ml}$ serum $25 \mathrm{OHD}$ ) are highly variable elsewhere: $100 \%$ of Somali immigrants in Sweden and $98 \%$ of Omani women, compared with $24 \%$ of Western Canadian women and 7\% of women from North Carolina

Published by Bioscientifica Ltd. 
(reviewed in Urrutia \& Thorp (2012)). Concerning the UK, The National Diet and Nutrition Survey reported that $28 \%$ of the female population aged 19-24 years had low serum vitamin D levels $(<25 \mathrm{nM}(<10 \mathrm{ng} / \mathrm{ml}))$ (Public Health England and Food Standards Agency 2014). Furthermore, serum $25 \mathrm{OHD}$ concentrations $<50 \mathrm{nM}(<20 \mathrm{ng} / \mathrm{ml})$ were reported in $49.5 \%$ of pregnant women in a recent UKbased prospective cohort study (Gale et al. 2008).

Defining vitamin D deficiency during pregnancy remains a major challenge. Maternal 25OHD levels do not appear to change significantly across pregnancy (Ginde et al. 2010). By contrast, serum levels of $1,25(\mathrm{OH})_{2} \mathrm{D}$ increase by approximately twofold during the first trimester, and peak during the third trimester (Brannon \& Picciano 2011). Renal synthesis of $1,25(\mathrm{OH})_{2} \mathrm{D}$ by the mother plays a key role in this elevation of maternal serum $1,25(\mathrm{OH})_{2} \mathrm{D}$ levels, but as outlined above, there is also evidence of local $1,25(\mathrm{OH})_{2} \mathrm{D}$ generation in both the placenta (fetal) and decidua (maternal) (Gray et al. 1979, Weisman et al. 1979). Early in pregnancy, the maternal decidua and fetal trophoblast cells show induced expression of both VDR and $1 \alpha$-hydroxylase (CYP27B1), the enzyme that catalyses conversion of $25 \mathrm{OHD}$ to $1,25(\mathrm{OH})_{2} \mathrm{D}$. By contrast, the vitamin D catabolic enzyme, 24-hydroxylase (CYP24A1), shows decreased expression in placental/decidual tissues across gestation (Zehnder et al. 2002, Evans et al. 2004). In this way, the placental/decidual tissues have the potential to generate significant amounts of $1,25(\mathrm{OH})_{2} \mathrm{D}$ without appreciable catabolic inactivation. Studies using nonpregnant rats demonstrated that conversion of $25 \mathrm{OHD}$ to $1,25(\mathrm{OH})_{2} \mathrm{D}$ was absent following nephrectomy, whereas synthesis of $1,25(\mathrm{OH})_{2} \mathrm{D}$ was still observed in pregnant rats (Weisman et al. 1978). This suggests that some $1,25(\mathrm{OH})_{2} \mathrm{D}$ produced by the placenta can spill over into the maternal circulation. Despite this, it is not clear that placental/decidual CYP27B1 plays a significant role in elevating maternal circulating levels of $1,25(\mathrm{OH})_{2} \mathrm{D}$. A single case report of a pregnant woman on chronic haemodialysis reported only mildly elevated circulating concentrations of $1,25(\mathrm{OH})_{2} \mathrm{D}$ relative to pre-pregnancy, with these levels being substantially lower than normal in pregnant women (Turner et al. 1988). Observations such as this suggest that the maternal kidneys are likely to be the most important site for maternal $1,25(\mathrm{OH})_{2} \mathrm{D}$ production during pregnancy. If this is the case, then the question arises as to whether there are alternative physiological functions of locally generated $1,25(\mathrm{OH})_{2} \mathrm{D}$ within the maternal and fetal utero-placental tissues.
One possibility is that $1,25(\mathrm{OH})_{2} \mathrm{D}$ generated by either the placenta or decidua acts to facilitate the transport of calcium and/or phosphate across the placenta to support fetal skeletal development (reviewed in Kovacs \& Kronenberg (1997)). It has previously been postulated that the observed increase in $1,25(\mathrm{OH})_{2} \mathrm{D}$ levels in pregnancy represents a normal physiological response to increased calcium requirements (Lund \& Selnes 1979, Kooh \& Vieth 1980), and that either a pregnancy-specific, or calcium homeostatic stimulus, such as oestrogen (Murphy et al. 1980), human placental lactogen (Josinovich 1969), or parathyroid hormone (Garabedian et al. 1974), which concomitantly increase throughout pregnancy, is implicated in this process. However, other groups have presented evidence suggesting that, in pregnancy, both calcium mobilisation from bone and intestinal transport occur by a vitamin D-independent mechanism (Van Cromphaut et al. 2003). Furthermore, calcium supply to the fetus is not negatively influenced by vitamin D deficiency (Halloran \& DeLuca 1980). Other reports have indicated that expression of the VDR is not required for fetal-placental calcium homoeostasis (Kovacs et al. 2005). Similarly, mineralisation of fetal bones occurs relatively late in pregnancy, while the induction of VDR and CYP27B1 in both maternal and fetal placental tissues occurs early in gestation, and thus alternative actions for intracrine $1,25(\mathrm{OH})_{2} \mathrm{D}$ have to be taken into consideration now (Evans et al. 2004). These include possible effects on fetal development through homeobox gene expression (Du et al. 2005) and placental vascularisation (Woodham et al. 2011). Studies by ourselves and others have supported an immunomodulatory function for vitamin D within the placenta and the specific role of maternal decidua in this process becomes the major focus of the current review.

\section{Vitamin $D$ and placental immunology}

A role for vitamin $\mathrm{D}$ as a potential modulator of immune responses during pregnancy was first postulated over 50 years ago, with specific reference to implantation (Chambon 1951), but the specific mechanisms by which this may be achieved have only recently gained further attention (Reichrath \& Querings 2005). In a similar fashion, a potential role for the placental vitamin D system in promoting anti-inflammatory responses against bacteria and, more recently, viral pathogens have been proposed (Mehta et al. 2009, Baeke et al. 2010). This has occurred in large because of recent advances in our understanding of how vitamin $\mathrm{D}$ interacts with the immune system: it is now clear that vitamin D can

Published by Bioscientifica Ltd.

Downloaded from Bioscientifica.com at $04 / 26 / 2023$ 12:43:49PM via free access 
influence both the innate and adaptive (acquired) arms of the immune system (Adams \& Hewison 2008, Hewison 2011). The remainder of this review will explore these interactions in more detail with specific reference to the individual groups of immune cells present in the decidua.

\section{Decidual macrophages}

Macrophages are the second most abundant immune cell type in the decidua, representing $\sim 20 \%$ of decidual immune cells (Salamonsen et al. 2007, Bulmer et al. 2010). Derived from blood monocytes they execute a wide array of critical immunological functions including phagocytosis and the subsequent intracellular killing of internalised pathogens, antigen presentation and cytokine secretion (Fujiwara \& Kobayashi 2005). As such, they play a pivotal role in orchestrating the innate and adaptive arms of the immune system.

As well as being able to phagocytose pathogens such as bacteria and viruses, macrophages and their precursor monocytes can also sense pathogen-associated molecular patterns (PAMPs) by utilising pattern-recognition receptors (PRRs), such as toll-like receptors (TLRs) (Takeda \& Akira 2005). In 2006, studies to identify monocyte genes regulated in response to the tuberculosis pathogen $\mathrm{Myco}$ bacterium tuberculosis showed induction of CYP27B1 and VDR expression following M. tuberculosis PAMP-sensing by TLR2/1 (Liu et al. 2006). This observation suggested that these cells promote cell-specific activation of vitamin $\mathrm{D}$ in response to $M$. tuberculosis, with the resulting $1,25(\mathrm{OH})_{2} \mathrm{D}$ binding to endogenous VDR. This 'intracrine' system allows vitamin $\mathrm{D}$ to modulate gene expression in response to an immune challenge against $M$. tuberculosis. Potential targets for intracrine activation of vitamin $\mathrm{D}$ include the antibiotic protein cathelicidin, which is a direct transcriptional target for the $1,25(\mathrm{OH})_{2} \mathrm{D}-\mathrm{VDR}$ complex (Wang et al. 2004, Gombart et al. 2005). Functional analyses showed that 25D-mediated induction of cathelicidin in monocytes promotes intracellular killing of M. tuberculosis (Liu et al. 2006). Thus, although TLR2/1 responses to M. tuberculosis initially involve activation of monocyte CYP27B1 and VDR gene expression, the efficacy of subsequent antibacterial activity ultimately depends on the availability of $25 \mathrm{OHD}$ for intracrine conversion to $1,25(\mathrm{OH})_{2} \mathrm{D}$. In this way, vitamin $\mathrm{D}$ status may be a key determinant of monocyte antibacterial responses, and variations in human serum 25OHD have been shown to correlate with induction of monocyte cathelicidin (Liu et al. 2006). The conclusion from these studies was that low serum 25OHD is less able to support monocyte antibacterial activity, with an increased risk of infection. Conversely, supplementation of vitamin D-insufficient individuals may improve monocyte cathelicidin production (Adams et al. 2009) and help to protect against infection.

Demonstration of a vitamin D-dependent, pathogenmediated antibacterial response in monocytes from peripheral blood has raised the possibility that similar innate immune responses will be present in monocytes and macrophages from other tissues (Bacchetta et al. 2013). Purification of decidual cells into non-adherent stromal cells and adherent cells, which include decidual macrophages and uNK cells, showed that adherent cells demonstrate a greater capacity for $1,25(\mathrm{OH})_{2} \mathrm{D}$ production (Kachkache et al. 1993). In view of the lack of evidence for functional expression of CYP27B1 in NK cells, including uNK cells, it seems likely that decidual macrophages will play a significant role in the localised generation of $1,25(\mathrm{OH})_{2} \mathrm{D}$ within the decidua. What is less clear is the immune impact of $1,25(\mathrm{OH})_{2} \mathrm{D}$ in this setting. One possibility is that decidual monocytes and macrophages will promote the same antibacterial responses observed for equivalent cells from the peripheral blood. Although, to date, this possibility has not been addressed in purified decidual monocytes/macrophages, studies using unpurified first-trimester decidual cells have shown 25OHD- and $1,25(\mathrm{OH})_{2} \mathrm{D}$-mediated induction of cathelicidin (Evans et al. 2006). It is also important to recognise that intracrine activation of vitamin D promotes antibacterial responses beyond simple induction of cathelicidin and other antibacterial proteins such as $\beta$-defensins (Liu et al. 2009). These include the induction of autophagy (Shin et al. 2011) and possible effects on intracellular iron concentrations via the iron export modulator hepcidin (Bacchetta et al. 2014). Crucially, these mechanisms are focused on an intracellular function for vitamin $\mathrm{D}$, and enhanced antibacterial responses to vitamin $\mathrm{D}$ are optimal for intracellular pathogens such as M. tuberculosis. As yet, it is not clear whether similar pathogens and the associated antimicrobial responses will be evident in the decidua. Indeed, it is possible that decidual vitamin $\mathrm{D}$ will support alternative antimicrobial responses including potential antiviral activity (Equils \& Hewison 2010).

Beyond their established innate antimicrobial activity, macrophages also play a pivotal role in tissue inflammation and antigen presentation, and both of these facets of immunity are crucial to normal decidual function. In the context of inflammation, macrophages can be categorised according to their functional role, comprising pro-inflammatory and anti-inflammatory subtypes. Analogous to the concept of different groups of

Published by Bioscientifica Ltd. 
$\mathrm{T}$ helper (Th) cells, macrophages activated under the influence of pro-inflammatory cytokines (such as interferon $\gamma(\mathrm{IFN} \gamma$ ) and tumour necrosis factor $\alpha$ (TNF $\alpha)$ ) have been termed ' $\mathrm{M} 1$ ', while those induced via exposure to Th2 cytokines (interleukin 4 (IL4), IL10 and IL13) are termed 'M2'. M1 subtypes, which have potent antimicrobial and cytotoxic properties, are subsequently implicated in microbial killing and autoimmune disease, whereas M2 subtypes convey a distinct immunosuppressive phenotype consistent with a role in humoral immunity and repair (Mosser 2003, Gordon \& Martinez 2010). This plasticity is demonstrated by acquisition of distinct morphological and functional properties and appears to be tissue specific (Houser et al. 2011)

In the decidua, M1 macrophages are postulated to participate in the progression of inflammation, whereas M2 decidual macrophages serve to promote fetal-maternal immune tolerance, tissue remodelling and scavenging of apoptotic cells (Erlebacher 2013a,b). Comparison between first- and second-trimester leukocyte populations has recently found that, although there was a significant decline in total macrophage numbers, a CD163 ${ }^{+} \mathrm{CD} 206^{+}$ subset designating alternatively activated pro-tolerogenic M2-like macrophages concomitantly increased (Kwan et al. 2014). Microarray gene expression analysis of human 1st-trimester decidua-derived macrophages has also revealed gene expression patterns associated with M1 and M2 macrophages (Gustafsson et al. 2008). In addition to their enhanced immune-modulatory potential, decidual macrophages also demonstrated a higher proliferative and tissue remodelling capacity, when compared with their peripheral blood counterparts (Gustafsson et al. 2008).

In the context of adverse pregnancy, elevated serum concentrations of IL12 (which augment the production of inflammatory cytokines) have also been measured in the peripheral blood of women with pre-eclampsia (PET) (Saito et al. 1999). Lower levels of anti-inflammatory IL10 have also been reported in the decidua basalis in cases of PET (Schonkeren et al. 2011, Darby et al. 2013). Polarisation towards an M2 macrophage subtype has also been observed in normal-term placentas relative to those from women with pregnancies complicated by both preterm birth and PET. M2 macrophage numbers in relation to total macrophages (CD163/CD14 ratio) were lower in placentas from preterm PET pregnancies compared with those from preterm 'controls'. Interestingly, total macrophage numbers were significantly higher in the PET group and positively correlated with PET severity (Schonkeren et al. 2011). However, although this shift towards a pro-inflammatory cytokine environment is described in the context of malplacentation disorders, this is an over-simplification; contradictory information exists as outlined later in this review. Certainly, a more detailed understanding of whether Th1 cytokine activity drives local dysregulation of immunoregulatory mechanisms in PET is required (Heikkinen et al. 2001) and, furthermore, whether vitamin D status is important to this. It is interesting to note that, in mouse models of inflammation and pregnancy, loss of the placental vitamin D intracrine system as a consequence of $V d r$ or $C y p 27 b 1$ gene knockout greatly exaggerates pro-inflammatory activity in the placenta (Liu et al. 2011).

\section{Dendritic cells}

Monocytes can also differentiate into DCs $\left(\mathrm{CD} 83^{+}\right)$, which populate the decidua throughout pregnancy (Laskarin et al. 2007). In human decidua, DCs are relatively sparse compared with macrophages ( $\sim 1 \%$ of total decidual cells (Kammerer et al. 2000)), questioning the functional importance of these cells in the decidua (Rieger et al. 2004). Macrophages and DCs share the ability to act as APCs, and both cells may therefore coordinate innate and adaptive immune responses in human pregnancy by balancing maternal immune responses against foreign antigens with protection of the semi-allogenic conceptus (Kammerer et al. 2000). First-trimester human $\mathrm{CD} 3^{+}$ decidual DCs possess $\mathrm{T}$ cell immune-stimulatory capacity in ex vivo mixed leukocyte reactions and also cluster with T cells in situ (Kammerer et al. 2000). Decidual DCs appear to be more tolerogenic than their peripheral blood counterparts, with a lower capacity for antigen presentation, reduced expression of co-stimulatory molecules, reduced expression of inflammatory cytokines such as IL12 and enhanced expression of anti-inflammatory cytokines such as IL10 (Laskarin et al. 2007, Arck et al. 2013). This is consistent with an immature DC phenotype that is generally associated with a more tolerogenic T-cell response (Kammerer et al. 2003). Recent data obtained specifically from 1st- and 2nd-trimester decidua support this, as maturation of DC precursors towards the inflammatory $\mathrm{CD} 3^{+}$DC subtype appears to be inhibited, given that no change in either $\mathrm{CD}^{209^{+}}$(immature) or mature $\mathrm{CD}^{+} 3^{+}$populations was observed, whereas the intermediate $\mathrm{CD} 205^{+}$DC subtype significantly declined (Kwan et al. 2014).

DC activity in decidua may also be modulated through other mechanisms. In murine models of pregnancy, a phenomenon known as 'DC entrapment' has

Published by Bioscientifica Ltd. 
been reported, where decidual DCs fail to migrate to uterine lymph nodes following their activation (Collins et al. 2009). It has been postulated that this may serve to limit adaptive $\mathrm{T}$ cell responsiveness towards fetal/placental antigens and restrict immunosurveillance specifically at the maternal-fetal interface.

As yet, it is unclear whether antigen presentation in the decidua is associated with a specific APC type. However, it would appear that both macrophages and DCs can utilise vitamin D through intracrine pathways (Kreutz et al. 1993, Hewison et al. 2003). In vitro, $1,25(\mathrm{OH})_{2} \mathrm{D}$ inhibits the differentiation and maturation of DCs through binding to the VDR (Griffin et al. 2001). Similar to macrophages (Kreutz et al. 1993), DCs derived from peripheral blood show differentiation-dependent changes in expression of VDR and CYP27B1 (Hewison et al. 2003). Using this intracrine system, 25OHD acts to inhibit DC maturation, as characterised by reduced cell surface expression of major histocompatibility (MHC) class II, CD40, CD80 and CD86 (Griffin et al. 2000). As a result, T cells stimulated by DCs in the presence of 25OHD have decreased proliferative capacity and a more tolerogenic phenotype (Hewison et al. 2003, Jeffery et al. 2012). Both a relative increase in T cell expression of IL10 when compared with IFN $\gamma$ and enhanced Treg functionality have been reported in vitamin D-treated DCs (Hewison et al. 2003, Jeffery et al. 2012).

In contrast to the wealth of recent data for DCs from peripheral blood, the exact role of DCs within the decidua is much less clear, particularly with respect to vitamin $\mathrm{D}$ responses. In studies of recurrent PET (Huang et al. 2008), and recurrent miscarriage (Askelund et al. 2004), an overabundance of decidual DCs has been observed, suggesting that DCs may be involved in the aetiology of some adverse events in pregnancy. The presence of an active intracrine system for vitamin D in DCs strongly suggests that variations in maternal 25OHD may have a significant effect on DC recruitment, maturation and antigen presentation. In future studies, it will be important to assess the impact of vitamin D status on decidual DC function. However, in addressing this, it is unclear how effective animal models will be, given that mice lacking uterine DCs do not show obvious reproductive deficits (Huang et al. 2008).

\section{Decidual/uterine NK cells}

In contrast with peripheral blood, in which only $10 \%$ of total lymphocytes are of NK origin (characterised by the cell surface antigen CD56), uNK cells account for a major proportion of the stromal leukocyte population in the decidua. uNK cells differ phenotypically from the majority of peripheral blood NK cells, being CD56-bright, CD16 negative and CD9 positive and showing distinct expression of both inhibitory and activating NK receptors (Trundley \& Moffett 2004, Bulmer \& Lash 2005, Bulmer et al. 2010). They are present in non-pregnant endometrium throughout the menstrual cycle but increase in number in the mid-secretory phase with a further increase in pregnancy to account for $70 \%$ of the total decidual stromal immune cell population (Bulmer et al. 2010). The number of uNK cells decreases in the second half of pregnancy, although a substantial number persists in the third trimester (Scaife et al. 2003).

The mechanisms that underpin the increased number of uNK cells in secretory-phase endometrium and early pregnancy are not fully understood. Recruitment of $\mathrm{CD}^{+} 6^{+}$cells to the decidua has been suggested, either through increased expression of the chemokine receptors CXCR4 and CCR5 both by decidual cells and invading extravillous trophoblast cells (Hanna et al. 2003). There is other evidence that uNK cells develop in situ within endometrium, either from haematopoietic stem cells (Lynch et al. 2007, Vacca et al. 2011) or from immature NK cell precursors (Male et al. 2010). In addition, uNK cells actively proliferate in secretory-phase endometrium, with up to $40 \%$ of CD56 cells in mid- and late-secretory-phase endometrium co-expressing the cell proliferation marker Ki67 (Bulmer, unpublished observations (Pace et al. 1989)). Transforming growth factor $\beta$ (TGF $\beta$ ) and IL15, both of which are produced by decidua in early pregnancy, are able to promote maturation of peripheral NK precursors towards uNK cells (Keskin et al. 2007). Array studies have indicated that uNK cells from early pregnancy and non-pregnant endometrium are distinct from each other and that in turn both populations are distinct from peripheral blood NK cells (Kopcow et al. 2010). In addition, uNK cells also demonstrate decreased cytotoxic capabilities and enhanced expression of a range of cytokines, chemokines and growth factors relative to peripheral blood NK cells (Hanna et al. 2003, Lash et al. 2010a). Indeed, the phenotype and cytokine/chemokine production of uNK cells have been reported to alter at different gestational ages with increased cytokine production and reduced angiogenic growth factor production at 12-14 weeks compared with $8-10$ weeks gestational age.

The prominence of uNK cells around the time of implantation and early placentation has suggested a fundamental role in the establishment of successful pregnancy. Furthermore, numbers of uNK cells have been reported to be altered in pre-eclampsia (Williams et al. 2009), although results are inconsistent, and several

Published by Bioscientifica Ltd.

Downloaded from Bioscientifica.com at $04 / 26 / 2023$ 12:43:49PM via free access 
groups have reported increased uNK cells in mid-secretoryphase endometrium from women with a history of recurrent miscarriage or recurrent implantation failure (Clifford et al. 1999, Laird et al. 2003, Quenby \& Farquharson 2006). As the uNK cells are the predominant decidual leukocyte population in early pregnancy, many roles have been suggested for them. Identification of high numbers of $\mathrm{CD}^{+} 6^{+}$cells later in third-trimester samples suggests that the role of uNK cells may even be more far reaching than anticipated (Bulmer et al. 2010, Lash et al. 2010a). However, despite numerous in vitro studies of function, the in vivo role of uNK cells remains unclear.

The effects of vitamin D on both peripheral blood and uterine NK cells have been poorly defined. In peripheral blood mononuclear cells, $1,25(\mathrm{OH})_{2} \mathrm{D}$ inhibits NK cell activation and cytotoxic actions in a time- and dosedependent manner (Merino et al. 1989). The cytokines IFN $\gamma$ and IL2 have been reported to augment NK cytotoxic activity, and both precursor vitamin $\mathrm{D}$ and $1,25(\mathrm{OH})_{2} \mathrm{D}$ inhibit this function (Leung 1989). However, in this latter case, studies were carried out using a heterogeneous mix of immune cells and so the precise mechanism by which the NK cells respond to vitamin D is unclear. NK cells express mRNA for VDR and CYP27B1 (Moran-Auth et al. 2013), although it is still not clear whether this represents a functional intracrine system for synthesis of $1,25(\mathrm{OH})_{2} \mathrm{D}$ by these cells. Studies of vitamin D and uNK cells have also been very limited, but may help to elucidate the mechanisms underpinning some of the associations between vitamin $\mathrm{D}$ status and pregnancy outcomes. In studies using partially purified uNK cells from first-trimester human pregnancies, treatment with either 25OHD or $1,25(\mathrm{OH})_{2} \mathrm{D}$ ex vivo promoted antibacterial and anti-inflammatory responses (Evans et al. 2006). In view of the fact that vitamin D deficiency in humans (Bodnar et al. 2007b) and mice (Liu et al. 2013) has been linked to PET, it is interesting to speculate that uNK cells may play a role in the pathophysiology of this complication of pregnancy. uNK cells appear to play a pivotal role in spiral arteriole remodelling (Robson et al. 2012) and the regulation of extravillous trophoblast invasion into decidua basalis and superficial myometrium through the production of local cytokines and chemokines (Lash et al. 2010b). In mice lacking uNK cells, there is a failure of normal decidual artery modification, and decidual hypo-cellularity/necrosis is observed (Lash et al. 2010a). Incomplete spiral arteriolar transformation and failure of extravillous trophoblast invasion are together considered to be responsible for placental underperfusion and may thus underlie the pathogenesis of both PET and intrauterine growth restriction (IUGR).
Another subtype of NK cells that accumulate with decidua are the CD1d-reactive natural killer T (NKT) cells, which have an invariant $\mathrm{T}$ cell receptor rearrangement (Boyson et al. 2008). Murine data suggest that NKT cell activation may induce preterm birth as well as pregnancy loss during the period from early gestation to midgestation (Boyson et al. 2006). As NKT cells are known to activate a number of other leukocyte subsets, it has been hypothesised that activation of NKT cells is the first step in a cascade of adverse anti-tolerogenic effects that may then lead to preterm birth (Boyson et al. 2008). As yet, there have been no studies to assess the impact of vitamin D on decidual NKT function and pregnancy outcome. However, in studies carried out in mice, variations in vitamin D status (maternal serum 25OHD) in utero have been shown to result in altered NKT cell function of the resulting offspring (Yu \& Cantorna 2011). This clearly has important implications for the potential impact of maternal vitamin D status on child health in humans.

\section{T cells}

Maternal tolerance of the fetus is generally not compromised by the production of $\mathrm{T}$ cells specific for fetal antigens during pregnancy. The mechanisms by which tolerance is maintained have gained much interest in recent years, and an increasingly complex, multi-faceted system has gradually been elucidated. $\mathrm{CD}^{+}$ $\mathrm{T}$ lymphocytes (T cells) comprise $\sim 10 \%$ of the endometrial stromal leukocyte population in first trimester decidua and are of both helper T cell $\left(\mathrm{CD}^{+}\right)$and cytotoxic $\mathrm{T}$ cell $\left(\mathrm{CD}^{+}\right)$subtypes. In contrast to the peripheral blood where $\mathrm{CD}^{+} \mathrm{CD}^{+}$cells predominate, decidual $\mathrm{CD}^{+}{ }^{+} \mathrm{CD} 4^{+} \mathrm{T}$ cells are less abundant $\left(\mathrm{CD}^{+}: \mathrm{CD} 4^{+}\right.$, ratio $3: 1)$. In first-trimester human decidua, $\sim 30-45 \%$ of $\mathrm{T}$ cells are $\mathrm{CD}^{+}$, and $45-75 \%$ are $\mathrm{CD}^{+} \mathrm{T}$ cells (Bulmer et al. 2010). Both subtypes have immunosuppressive functions and may be involved in mediating maternofetal tolerance, particularly as pregnancy evolves (Blois et al. 2004).

Activation of naive Th cells by antigen leads to the generation of $\mathrm{CD} 4^{+}$Th subgroups with distinct cytokine profiles: Th1 (IL2, IFN $\gamma$ and TNF $\alpha$ ) and Th2 (IL3, IL4, IL5 and IL10), which respectively support cell-mediated and humoral immunity (Abbas et al. 1996, Romagnani 2006). A third group of Th cells known to be influenced by vitamin D are IL17-secreting T-cells (Th17 cells). Initially, it was believed that pregnancy reflects an immune setting dominated by Th2 cytokines (Wegmann et al. 1993). However, this is not absolute and a local Th2 dominance

Published by Bioscientifica Ltd.

Downloaded from Bioscientifica.com at $04 / 26 / 2023$ 12:43:49PM via free access 
has not been consistently demonstrated in term decidual samples (Athanassakis \& Vassiliadis 2002). Elevated levels of decidual Th17 cells have been reported in spontaneous abortion (Saito et al. 2010) and increased decidual Th1/Th2 ratios in recurrent spontaneous abortion (Piccinni et al. 1998). As conflicting data again exist, there appears a more complex $\mathrm{T}$ cell response and cytokine paradigm in which reciprocal Treg and Th17 cell pathways are also implicated (Bates et al. 2002, Saito et al. 2010).

One of the initial observations linking vitamin $\mathrm{D}$ to the adaptive immune system was that $\mathrm{T}$ cells express VDR, with these levels increasing as $\mathrm{T}$ cells proliferate (Nunn et al. 1986). As a consequence, initial studies of vitamin $D$ and $\mathrm{T}$ cells focused on anti-proliferative responses (Nunn et al. 1986, Provvedini \& Manolagas 1989, Karmali et al. 1991). However, it is now clear that vitamin D also influences the phenotype of $\mathrm{T}$ cells, in part by promoting a shift from Th1 cytokine profile to Th2 (Lemire et al. 1995, Overbergh et al. 2000, Boonstra et al. 2001). In this way, it has been proposed that vitamin D could limit potential tissue damage associated with excessive Th1 cellular immune responses by switching to a more humoral Th2 phenotype. However, the validity of this hypothesis is uncertain as $V d r$ gene knockout mice (which lack $1,25(\mathrm{OH})_{2} \mathrm{D}$-mediated signalling) have reduced rather than elevated levels of Th1 cells (O'Kelly et al. 2002).

Thus, it seems likely that effects of vitamin D on T cells in vivo are more complex than thought originally, with other cells such as inflammatory Th17 cells being the potential targets. Th17 cells are important for promoting immune responses to some pathogens, but they have also been linked to inflammatory tissue damage (Bettelli et al. 2007, Korn et al. 2007). Exposure to $1,25(\mathrm{OH})_{2} \mathrm{D}$ in vitro suppresses Th17 cell development (Colin et al. 2010, Palmer et al. 2010) and expression of IL17 (IL17A) (Daniel et al. 2008) respectively. Paradoxically, Cyp27b1 gene knockout leads to elevated levels of IL17 (Liu et al. 2008). Recent studies using a rat model of pre-eclampsia demonstrated that vitamin $\mathrm{D}$ supplementation significantly decreased circulating CD $4^{+}$Th cells (Darby et al. 2013). However, in the same study, cytokine levels from human whole-placenta explants from both normal pregnant women and those complicated by PET following culture in both hypoxic and normoxic conditions were assessed. Expression of Th2-associated IL10 was significantly decreased, and that of Th1-associated IL6 increased in pre-eclampsia explants compared with controls, but this was unaffected by vitamin D (Darby et al. 2013).
T cell immune responses to vitamin $\mathrm{D}$ are not restricted to Th cells, but also include actions on suppressor Tregs, a group of $\mathrm{CD}^{+}{ }^{+} \mathrm{T}$ cells known to inhibit the proliferation of other $\mathrm{CD} 4{ }^{+} \mathrm{T}$ cells. Treatment of naive $\mathrm{CD} 4^{+} \mathrm{T}$ cells with $1,25(\mathrm{OH})_{2} \mathrm{D}$ potently induces the development of Tregs (Gorman et al. 2007), and this has been proposed as a mechanism for potential beneficial effects of vitamin D on autoimmune disease and host-graft rejection (Gregori et al. 2002, Mathieu \& Badenhoop 2005, Spach et al. 2006). In stimulating Treg development, $1,25(\mathrm{OH})_{2} \mathrm{D}$ may act directly on VDR-expressing CD4 ${ }^{+} \mathrm{T}$ cells (Jeffery et al. 2009, Urry et al. 2009). However, as outlined earlier in this review, it may also act via effects on APCs such as DCs or macrophages (Gregori et al. 2001, Dong et al. 2003, Adorini et al. 2004). In common with helper and Tregs, CD8 ${ }^{+}$ cytotoxic T cells express VDR and are sensitive to cytokine regulation by $1,25(\mathrm{OH})_{2} \mathrm{D}$ (Willheim et al. 1999). Recent studies have demonstrated that $V d r$ gene knockout in mice leads to dysregulation of $\mathrm{CD}^{+} \mathrm{T}$ cell proliferation and increased risk of inflammatory disease in these animals (Chen et al. 2014). Intriguingly, these studies also suggested that these murine $\mathrm{CD} 8^{+}$cells are the major site of immune synthesis of $1,25(\mathrm{OH})_{2} \mathrm{D}$ (Ooi et al. 2014).

Fetal protection from rejection by $\mathrm{T}$ cells reactive to fetal antigens has been attributed to clonal deletion or suppressed proliferation of $\mathrm{T}$ cells. The inhibitory costimulatory molecule programmed death 1 (PD1) receptor, the cell surface death receptor FAS and indoleamine 2,34 deoxygenase (IDO)-dependent pathways have all been implicated in this process, as their respective ligands are expressed by decidual and fetal trophoblast cells in human and mouse pregnancies (Arck \& Hecher 2013). Studies on mice have indicated that although independently these $\mathrm{T}$ cell-constraining pathways are not critical for fetal survival and development, their immunoregulatory functions are still important and may be targeted by vitamin D. For example, $1,25(\mathrm{OH})_{2} \mathrm{D}$ stimulates $\mathrm{CD} 4{ }^{+} \mathrm{CD}_{2} 5^{+} \mathrm{FoxP}^{+}{ }^{+} \mathrm{T}$ cell production through an IDO-mediated pathway (Correale et al. 2009). Preliminary data from our group using decidual cells found that expression of CYP27B1 correlated with TLR4 and IDO (IDO1) expression (Evans et al. 2006). Functional responses to $1,25(\mathrm{OH})_{2} \mathrm{D}$ were studied in the context of uNK cells as opposed to decidual $\mathrm{T}$ cells in this instance, but nevertheless data demonstrated a shift towards a pro-tolerogenic cytokine profile.

\section{B cells}

Decidual B cells are present during human pregnancy, but in very low numbers compared with $\mathrm{T}$ cells

Published by Bioscientifica Ltd. 
(Rieger et al. 2009). Consequently, they have received less research attention, despite the fact that in pregnant women there appear to be distinct differences in circulating B cell subtypes when compared with non-pregnant women (Fettke et al. 2014). In particular, IL10-secreting B cells termed B10 cells, which have been linked to protection against autoimmune disease (Matsushita et al. 2008), appear to play a key role in pregnancy by promoting tolerance of the developing fetus in mice (Jensen et al. 2013). As yet, the function of these cells specifically within the decidua remains unclear.

As with $\mathrm{T}$ cells, $1,25(\mathrm{OH})_{2} \mathrm{D}$ can also suppress proliferation (Shiozawa et al. 1985) and immunoglobulin (Ig) production (Provvedini et al. 1986) in VDR-expressing B cells. Initially this was thought to be mediated via an indirect, $\mathrm{T}$ cell-dependent, mechanism, but more recent reports have endorsed a direct effect of $1,25(\mathrm{OH})_{2} \mathrm{D}$ on $B$ cells (Chen et al. 2007). Moreover, besides confirming the anti-proliferative actions of $1,25(\mathrm{OH})_{2} \mathrm{D}$ on B cells, these studies demonstrated that $1,25(\mathrm{OH})_{2} \mathrm{D}$ can inhibit the differentiation of plasma cells and class-switched memory cells (Chen et al. 2007), highlighting a potential role for vitamin D in B cell-related disorders such as systemic lupus erythematosus. The implications of these findings for human pregnancy remain unclear as yet. Nevertheless, it is possible to speculate that maternal vitamin $\mathrm{D}$ deficiency may lead to dysregulation of decidual B cell function with potential adverse outcomes.

\section{Conclusions}

Pregnancy presents a unique immune challenge for the maternal host, with the maternal-fetal interface being the prime area of immune regulation. In this setting, the immune cells within the heterogeneous population of cells that make up the maternal decidua play a key role in maintaining tolerance of the developing fetus while protecting the conceptus against infection and inflammation. Successful maintenance of this complex decidual immune system requires an equally complex set of regulatory factor and, in this setting, vitamin D may play a highly versatile role by promoting antibacterial innate immune responses to infection while suppressing adverse inflammatory adaptive immunity. Several other features of vitamin D support its role as a regulator of decidual immunity. Crucially, the placenta is one of the principal sites for extra-renal synthesis of $1,25(\mathrm{OH})_{2} \mathrm{D}$, with both the maternal and fetal sides of the placenta cooperating to maintain high localised tissue levels of this hormone. This is likely to be a key factor in optimising the immune function of vitamin D, but may also be important in promoting the crosstalk between the maternal decidua and fetal trophoblast. However, it is important to recognise that the success of these decidual responses to vitamin $\mathrm{D}$ will be dependent on the availability of substrate 25OHD, so that tissue-specific levels of $1,25(\mathrm{OH})_{2} \mathrm{D}$ may be compromised under conditions of vitamin D-insufficiency. It is important that these mechanisms are identified in both human and murine pregnancy. The impact of this on immune function during pregnancy, particularly within the decidua, is likely to be a key component of future studies of vitamin $\mathrm{D}$ and pregnancy.

\section{Declaration of interest}

The authors declare that there is no conflict of interest that could be perceived as prejudicing the impartiality of this review.

\section{Funding}

This review was supported by a fellowship from Wellbeing of Women (RTF401) to J A T, and grants from Action Medical Research to M D K and WK Kellogg Foundation to $\mathrm{M} \mathrm{H}$ and C L W.

\section{References}

Abbas AK, Murphy KM \& Sher A 1996 Functional diversity of helper T lymphocytes. Nature 383 787-793. (doi:10.1038/383787a0) Adams JS \& Hewison M 2008 Unexpected actions of vitamin D: new perspectives on the regulation of innate and adaptive immunity. Nature Clinical Practice. Endocrinology \& Metabolism 4 80-90. (doi:10.1038/ ncpendmet0716)

Adams JS, Ren S, Liu PT, Chun RF, Lagishetty V, Gombart AF, Borregaard N, Modlin RL \& Hewison M 2009 Vitamin D-directed rheostatic regulation of monocyte antibacterial responses. Journal of Immunology $\mathbf{1 8 2}$ 4289-4295. (doi:10.4049/jimmunol.0803736)

Adorini L, Penna G, Giarratana N, Roncari A, Amuchastegui S, Daniel KC \& Uskokovic M 2004 Dendritic cells as key targets for immunomodulation by vitamin D receptor ligands. Journal of Steroid Biochemistry and Molecular Biology 89-90 437-441. (doi:10.1016/j.jsbmb.2004.03.013)

Alijotas-Reig J, Llurba E \& Gris JM 2014 Potentiating maternal immune tolerance in pregnancy: a new challenging role for regulatory $\mathrm{T}$ cells. Placenta 35 241-248. (doi:10.1016/j.placenta.2014.02.004)

Arck PC \& Hecher K 2013 Fetomaternal immune cross-talk and its consequences for maternal and offspring's health. Nature Medicine 19 548-556. (doi:10.1038/nm.3160)

Arck P, Solano ME, Maciej K \& Robertson S 2013 Reproductive immunology: piece by piece. Journal of Reproductive Immunology 971. (doi:10.1016/j.jri.2013.02.001)

Askelund K, Liddell HS, Zanderigo AM, Fernando NS, Khong TY, Stone PR \& Chamley LW 2004 CD83(+)dendritic cells in the decidua of women with recurrent miscarriage and normal pregnancy. Placenta 25 140-145. (doi:10.1016/S0143-4004(03)00182-6)

Athanassakis I \& Vassiliadis S 2002 Interplay between T helper type 1 and type 2 cytokines and soluble major histocompatibility complex molecules: a paradigm in pregnancy. Immunology 107 281-287. (doi:10.1046/j.1365-2567.2002.01518.x) 
Bacchetta J, Sea JL, Chun RF, Lisse TS, Wesseling-Perry K, Gales B, Adams JS, Salusky IB \& Hewison M 2013 Fibroblast growth factor 23 inhibits extrarenal synthesis of 1,25-dihydroxyvitamin D in human monocytes. Journal of Bone and Mineral Research 28 46-55. (doi:10.1002/jbmr.1740)

Bacchetta J, Zaritsky JJ, Sea JL, Chun RF, Lisse TS, Zavala K, Nayak A, Wesseling-Perry K, Westerman M, Hollis BW et al. 2014 Suppression of iron-regulatory hepcidin by vitamin D. Journal of the American Society of Nephrology 25 564-572. (doi:10.1681/ASN.2013040355)

Baeke F, Takiishi T, Korf H, Gysemans C \& Mathieu C 2010 Vitamin D: modulator of the immune system. Current Opinion in Pharmacology 10 482-496. (doi:10.1016/j.coph.2010.04.001)

Bates MD, Quenby S, Takakuwa K, Johnson PM \& Vince GS 2002 Aberrant cytokine production by peripheral blood mononuclear cells in recurrent pregnancy loss? Human Reproduction 17 2439-2444. (doi:10. 1093/humrep/17.9.2439)

Bettelli E, Korn T \& Kuchroo VK 2007 Th17: the third member of the effector T cell trilogy. Current Opinion in Immunology 19 652-657. (doi:10.1016/j.coi.2007.07.020)

Blois SM, Alba Soto CD, Tometten M, Klapp BF, Margni RA \& Arck PC 2004 Lineage, maturity, and phenotype of uterine murine dendritic cells throughout gestation indicate a protective role in maintaining pregnancy. Biology of Reproduction 70 1018-1023. (doi:10.1095/ biolreprod.103.022640)

Bodnar LM, Simhan HN, Powers RW, Frank MP, Cooperstein E \& Roberts JM 2007a High prevalence of vitamin D insufficiency in black and white pregnant women residing in the northern United States and their neonates. Journal of Nutrition 137 447-452.

Bodnar LM, Catov JM, Simhan HN, Holick MF, Powers RW \& Roberts JM $2007 b$ Maternal vitamin D deficiency increases the risk of preeclampsia. Journal of Clinical Endocrinology and Metabolism 92 3517-3522. (doi:10.1210/jc.2007-0718)

Boonstra A, Barrat FJ, Crain C, Heath VL, Savelkoul HF \& O'Garra A 2001 1 $\alpha, 25$-Dihydroxyvitamin $\mathrm{D} 3$ has a direct effect on naive CD4(+) T cells to enhance the development of Th2 cells. Journal of Immunology $\mathbf{1 6 7}$ 4974-4980. (doi:10.4049/jimmunol.167.9.4974)

Boyson JE, Nagarkatti N, Nizam L, Exley MA \& Strominger JL 2006 Gestation stage-dependent mechanisms of invariant natural killer T cell-mediated pregnancy loss. PNAS 103 4580-4585. (doi:10.1073/ pnas.0511025103)

Boyson JE, Aktan I, Barkhuff DA \& Chant A 2008 NKT cells at the maternalfetal interface. Immunological Investigations 37 565-582. (doi:10.1080/ 08820130802191409)

Brannon PM \& Picciano MF 2011 Vitamin D in pregnancy and lactation in humans. Annual Review of Nutrition 31 89-115. (doi:10.1146/annurev. nutr.012809.104807)

Brehm JM, Schuemann B, Fuhlbrigge AL, Hollis BW, Strunk RC, Zeiger RS, Weiss ST, Litonjua AA \& Childhood Asthma Management Program Research Group 2010 Serum vitamin D levels and severe asthma exacerbations in the Childhood Asthma Management Program study. Journal of Allergy and Clinical Immunology 126 52-58 e55. (doi:10.1016/j. jaci.2010.03.043)

Bulmer JN \& Lash GE 2005 Human uterine natural killer cells: a reappraisal. Molecular Immunology 42 511-521. (doi:10.1016/j.molimm.2004. 07.035)

Bulmer JN, Pace D \& Ritson A 1988 Immunoregulatory cells in human decidua: morphology, immunohistochemistry and function. Reproduction, Nutrition, Development 28 1599-1613. (doi:10.1051/ rnd:19881006)

Bulmer JN, Longfellow M \& Ritson A 1991 Leukocytes and resident blood cells in endometrium. Annals of the New York Academy of Sciences $\mathbf{6 2 2}$ 57-68. (doi:10.1111/j.1749-6632.1991.tb37850.x)

Bulmer JN, Williams PJ \& Lash GE 2010 Immune cells in the placental bed. International Journal of Developmental Biology 54 281-294. (doi:10.1387/ ijdb.082763jb)

Cannell JJ, Vieth R, Umhau JC, Holick MF, Grant WB, Madronich S, Garland CF \& Giovannucci E 2006 Epidemic influenza and vitamin D.
Epidemiology and Infection 134 1129-1140. (doi:10.1017/ S0950268806007175)

Chambon Y 1951 Synergic action of vitamin D and of progesterone in obtaining ovum implantation in the castrated pregnant rabbit. Comptes Rendus des Séances de la Société de Biologie et de Ses Filiales 145 955-959.

Chen S, Sims GP, Chen XX, Gu YY, Chen S \& Lipsky PE 2007 Modulatory effects of 1,25-dihydroxyvitamin D3 on human B cell differentiation. Journal of Immunology 179 1634-1647. (doi:10.4049/jimmunol.179.3.1634)

Chen J, Bruce D \& Cantorna MT 2014 Vitamin D receptor expression controls proliferation of naive $\mathrm{CD} 8{ }^{+} \mathrm{T}$ cells and development of CD8 mediated gastrointestinal inflammation. BMC Immunology 156. (doi:10.1186/1471-2172-15-6)

Clifford K, Flanagan AM \& Regan L 1999 Endometrial CD56 ${ }^{+}$natural killer cells in women with recurrent miscarriage: a histomorphometric study. Human Reproduction 14 2727-2730. (doi:10.1093/humrep/14.11.2727)

Colin EM, Asmawidjaja PS, van Hamburg JP, Mus AM, van Driel M, Hazes JM, van Leeuwen JP \& Lubberts E 2010 1,25-dihydroxyvitamin D3 modulates Th17 polarization and interleukin-22 expression by memory $\mathrm{T}$ cells from patients with early rheumatoid arthritis. Arthritis and Rheumatism 62 132-142. (doi:10.1002/art.25043)

Collins MK, Tay CS \& Erlebacher A 2009 Dendritic cell entrapment within the pregnant uterus inhibits immune surveillance of the maternal/fetal interface in mice. Journal of Clinical Investigation 119 2062-2073. (doi:10.1172/JCI38714)

Correale J, Ysrraelit MC \& Gaitan MI 2009 Immunomodulatory effects of vitamin D in multiple sclerosis. Brain 132 1146-1160. (doi:10.1093/ brain/awp033)

Daniel C, Sartory NA, Zahn N, Radeke HH \& Stein JM 2008 Immune modulatory treatment of TNBS colitis with calcitriol is associated with a change of a Th1/Th17 to a Th2 and regulatory T cell profile. Journal of Pharmacology and Experimental Therapeutics 324 23-33. (doi:10.1124/ jpet.107.127209)

Darby MM, Wallace K, Cornelius D, Chatman KT, Mosely JN, Martin JN, Purser CA, Baker RC, Owens MT \& Lamarca BB 2013 Vitamin D supplementation suppresses hypoxia-stimulated placental cytokine secretion, hypertension and $\mathrm{CD} 4^{+} \mathrm{T}$ cell stimulation in response to placental ischemia. Medical Journal of Obstetrics and Gynecology 11012.

Dong X, Bachman LA, Kumar R \& Griffin MD 2003 Generation of antigenspecific, interleukin-10-producing T-cells using dendritic cell stimulation and steroid hormone conditioning. Transplant Immunology $\mathbf{1 1}$ 323-333. (doi:10.1016/S0966-3274(03)00049-2)

Du H, Daftary GS, Lalwani SI \& Taylor HS 2005 Direct regulation of HOXA10 by 1,25-(OH)2D3 in human myelomonocytic cells and human endometrial stromal cells. Molecular Endocrinology 19 2222-2233. (doi:10.1210/me.2004-0336)

Equils O \& Hewison M 2010 A role for vitamin D in placental immunology. Journal of Infectious Diseases 201 1950-1951 author reply 1951. (doi:10.1086/652804)

Erlebacher A 2013a Immunology of the maternal-fetal interface. Annual Review of Immunology 31 387-411. (doi:10.1146/annurev-immunol032712-100003)

Erlebacher A 2013b Mechanisms of T cell tolerance towards the allogeneic fetus. Nature Reviews. Immunology 13 23-33. (doi:10.1038/nri3361)

Evans KN, Bulmer JN, Kilby MD \& Hewison M 2004 Vitamin D and placental-decidual function. Journal of the Society for Gynecologic Investigation 11 263-271. (doi:10.1016/j.jsgi.2004.02.002)

Evans KN, Nguyen L, Chan J, Innes BA, Bulmer JN, Kilby MD \& Hewison M 2006 Effects of 25-hydroxyvitamin D3 and 1,25-dihydroxyvitamin D3 on cytokine production by human decidual cells. Biology of Reproduction 75 816-822. (doi:10.1095/biolreprod.106.054056)

Fettke F, Schumacher A, Costa SD \& Zenclussen AC 2014 B cells: the old new players in reproductive immunology. Frontiers in Immunology $\mathbf{5}$ 285. (doi:10.3389/fimmu.2014.00285)

Fujiwara N \& Kobayashi K 2005 Macrophages in inflammation. Current Drug Targets. Inflammation and Allergy 4 281-286. (doi:10.2174/ 1568010054022024) 
Gale CR, Robinson SM, Harvey NC, Javaid MK, Jiang B, Martyn CN, Godfrey KM, Cooper C \& Princess Anne Hospital Study Group 2008 Maternal vitamin D status during pregnancy and child outcomes. European Journal of Clinical Nutrition 62 68-77. (doi:10.1038/sj.ejcn. 1602680)

Garabedian M, Tanaka Y, Holick MF \& Deluca HF 1974 Response of intestinal calcium transport and bone calcium mobilization to 1,25-dihydroxyvitamin D3 in thyroparathyroidectomized rats. Endocrinology 94 1022-1027. (doi:10.1210/endo-94-4-1022)

Gellersen B, Brosens IA \& Brosens JJ 2007 Decidualization of the human endometrium: mechanisms, functions, and clinical perspectives. Seminars in Reproductive Medicine 25 445-453. (doi:10.1055/s-2007991042)

Ginde AA, Sullivan AF, Mansbach JM \& Camargo CA Jr 2010 Vitamin D insufficiency in pregnant and nonpregnant women of childbearing age in the United States. American Journal of Obstetrics and Gynecology 202 436.e1-436.e8. (doi:10.1016/j.ajog.2009.11.036)

Gombart AF, Borregaard N \& Koeffler HP 2005 Human cathelicidin antimicrobial peptide (CAMP) gene is a direct target of the vitamin D receptor and is strongly up-regulated in myeloid cells by 1,25dihydroxyvitamin D3. FASEB Journal 19 1067-1077. (doi:10.1096/fj.043284com)

Gordon S \& Martinez FO 2010 Alternative activation of macrophages: mechanism and functions. Immunity 32 593-604. (doi:10.1016/j. immuni.2010.05.007)

Gorman S, Kuritzky LA, Judge MA, Dixon KM, McGlade JP, Mason RS, Finlay-Jones JJ \& Hart PH 2007 Topically applied 1,25-dihydroxyvitamin D3 enhances the suppressive activity of $\mathrm{CD} 4{ }^{+} \mathrm{CD} 25^{+}$cells in the draining lymph nodes. Journal of Immunology $1796273-6283$. (doi:10.4049/jimmunol.179.9.6273)

Grant WB \& Mohr SB 2009 Ecological studies of ultraviolet B, vitamin D and cancer since 2000. Annals of Epidemiology 19 446-454. (doi:10.1016/j.annepidem.2008.12.014)

Gray TK, Lester GE \& Lorenc RS 1979 Evidence for extra-renal $1 \alpha$-hydroxylation of 25 -hydroxyvitamin D3 in pregnancy. Science $\mathbf{2 0 4}$ 1311-1313. (doi:10.1126/science.451538)

Gregori S, Casorati M, Amuchastegui S, Smiroldo S, Davalli AM \& Adorini L 2001 Regulatory T cells induced by $1 \alpha, 25$-dihydroxyvitamin D3 and mycophenolate mofetil treatment mediate transplantation tolerance. Journal of Immunology 167 1945-1953. (doi:10.4049/jimmunol.167.4. 1945)

Gregori S, Giarratana N, Smiroldo S, Uskokovic M \& Adorini L 2002 A $1 \alpha, 25$-dihydroxyvitamin $\mathrm{D}(3)$ analog enhances regulatory T-cells and arrests autoimmune diabetes in NOD mice. Diabetes 51 1367-1374. (doi:10.2337/diabetes.51.5.1367)

Griffin MD, Lutz WH, Phan VA, Bachman LA, McKean DJ \& Kumar R 2000 Potent inhibition of dendritic cell differentiation and maturation by vitamin D analogs. Biochemical and Biophysical Research Communications 270 701-708. (doi:10.1006/bbrc.2000.2490)

Griffin MD, Lutz W, Phan VA, Bachman LA, McKean DJ \& Kumar R 2001 Dendritic cell modulation by $1 \alpha, 25$ dihydroxyvitamin D3 and its analogs: a vitamin D receptor-dependent pathway that promotes a persistent state of immaturity in vitro and in vivo. PNAS 98 6800-6805. (doi:10.1073/pnas.121172198)

Gustafsson C, Mjosberg J, Matussek A, Geffers R, Matthiesen L, Berg G, Sharma S, Buer J \& Ernerudh J 2008 Gene expression profiling of human decidual macrophages: evidence for immunosuppressive phenotype. PLOS ONE 3 e2078. (doi:10.1371/journal.pone.0002078)

Halloran BP \& DeLuca HF 1980 Calcium transport in small intestine during early development: role of vitamin D. American Journal of Physiology 239 G473-G479.

Hanna J, Wald O, Goldman-Wohl D, Prus D, Markel G, Gazit R, Katz G, Haimov-Kochman R, Fujii N, Yagel S et al. 2003 CXCL12 expression by invasive trophoblasts induces the specific migration of CD16 human natural killer cells. Blood 102 1569-1577. (doi:10.1182/blood2003-02-0517)
Haussler MR, Haussler CA, Bartik L, Whitfield GK, Hsieh JC, Slater S \& Jurutka PW 2008 Vitamin D receptor: molecular signaling and actions of nutritional ligands in disease prevention. Nutrition Reviews $6 \mathbf{6}$ S98-S112. (doi:10.1111/j.1753-4887.2008.00093.x)

Heikkinen J, Mottonen M, Pulkki K, Lassila O \& Alanen A 2001 Cytokine levels in midtrimester amniotic fluid in normal pregnancy and in the prediction of pre-eclampsia. Scandinavian Journal of Immunology $\mathbf{5 3}$ 310-314. (doi:10.1046/j.1365-3083.2001.00872.x)

Henry HL, Bouillon R, Norman AW, Gallagher JC, Lips P, Heaney RP, Vieth R, Pettifor JM, Dawson-Hughes B, Lamberg-Allardt CJ et al. 2010 14th Vitamin D Workshop consensus on vitamin D nutritional guidelines. Journal of Steroid Biochemistry and Molecular Biology 121 4-6. (doi:10.1016/j.jsbmb.2010.05.008)

Hewison M 2010 Vitamin D and the intracrinology of innate immunity. Molecular and Cellular Endocrinology 321 103-111. (doi:10.1016/j.mce. 2010.02.013)

Hewison M 2011 Vitamin D and innate and adaptive immunity. Vitamins and Hormones 86 23-62. (doi:10.1016/B978-0-12-386960-9.00002-2)

Hewison M, Freeman L, Hughes SV, Evans KN, Bland R, Eliopoulos AG, Kilby MD, Moss PA \& Chakraverty R 2003 Differential regulation of vitamin $\mathrm{D}$ receptor and its ligand in human monocyte-derived dendritic cells. Journal of Immunology 170 5382-5390. (doi:10.4049/ jimmunol.170.11.5382)

Hewison M, Burke F, Evans KN, Lammas DA, Sansom DM, Liu P, Modlin RL \& Adams JS 2007 Extra-renal 25-hydroxyvitamin D3-1 $\alpha$-hydroxylase in human health and disease. Journal of Steroid Biochemistry and Molecular Biology 103 316-321. (doi:10.1016/j.jsbmb.2006.12.078)

Holick MF 2007 Vitamin D deficiency. New England Journal of Medicine 357 266-281. (doi:10.1056/NEJMra070553)

Holick MF \& Chen TC 2008 Vitamin D deficiency: a worldwide problem with health consequences. American Journal of Clinical Nutrition $\mathbf{8 7}$ 1080S-1086S.

Holick MF, Binkley NC, Bischoff-Ferrari HA, Gordon CM, Hanley DA, Heaney RP, Murad MH \& Weaver CM 2011 Evaluation, treatment, and prevention of vitamin D deficiency: an Endocrine Society clinical practice guideline. Journal of Clinical Endocrinology and Metabolism 96 1911-1930. (doi:10.1210/jc.2011-0385)

Houser BL, Tilburgs T, Hill J, Nicotra ML \& Strominger JL 2011 Two unique human decidual macrophage populations. Journal of Immunology 186 2633-2642. (doi:10.4049/jimmunol.1003153)

Huang SJ, Chen CP, Schatz F, Rahman M, Abrahams VM \& Lockwood CJ 2008 Pre-eclampsia is associated with dendritic cell recruitment into the uterine decidua. Journal of Pathology 214 328-336. (doi:10.1002/ path.2257)

Hypponen E, Laara E, Reunanen A, Jarvelin MR \& Virtanen SM 2001 Intake of vitamin $\mathrm{D}$ and risk of type 1 diabetes: a birth-cohort study. Lancet 358 1500-1503. (doi:10.1016/S0140-6736(01)06580-1)

Jeffery LE, Burke F, Mura M, Zheng Y, Qureshi OS, Hewison M, Walker LS, Lammas DA, Raza K \& Sansom DM 2009 1,25-Dihydroxyvitamin D(3) and IL-2 combine to inhibit T cell production of inflammatory cytokines and promote development of regulatory $\mathrm{T}$ cells expressing CTLA-4 and FoxP3. Journal of Immunology 183 5458-5467. (doi:10.4049/jimmunol.0803217)

Jeffery LE, Wood AM, Qureshi OS, Hou TZ, Gardner D, Briggs Z, Kaur S, Raza K \& Sansom DM 2012 Availability of 25-hydroxyvitamin D3 to APCs controls the balance between regulatory and inflammatory $\mathrm{T}$ cell responses. Journal of Immunology 189 5155-5164. (doi:10.4049/ jimmunol.1200786)

Jensen F, Muzzio D, Soldati R, Fest S \& Zenclussen AC 2013 Regulatory B10 cells restore pregnancy tolerance in a mouse model. Biology of Reproduction 89 90. (doi:10.1095/biolreprod.113.110791)

Josinovich JB 1969 Human Placental Lactogen., New York: Academic Press, Inc.

Kachkache M, Rebut-Bonneton C, Demignon J, Cynober E \& Garabedian M 1993 Uterine cells other than stromal decidual cells are required for 
1,25-dihydroxyvitamin D3 production during early human pregnancy. FEBS Letters 333 83-88. (doi:10.1016/0014-5793(93)80379-9)

Kammerer U, Schoppet M, McLellan AD, Kapp M, Huppertz HI, Kampgen E \& Dietl J 2000 Human decidua contains potent immunostimulatory CD83(+) dendritic cells. American Journal of Pathology 157 159-169. (doi:10.1016/S0002-9440(10)64527-0)

Kammerer U, Eggert AO, Kapp M, McLellan AD, Geijtenbeek TB, Dietl J, van Kooyk Y \& Kampgen E 2003 Unique appearance of proliferating antigen-presenting cells expressing DC-SIGN (CD209) in the decidua of early human pregnancy. American Journal of Pathology 162 887-896. (doi:10.1016/S0002-9440(10)63884-9)

Karmali R, Hewison M, Rayment N, Farrow SM, Brennan A, Katz DR \& O'Riordan JL 1991 1,25(OH)2D3 regulates c-myc mRNA levels in tonsillar T lymphocytes. Immunology 74 589-593.

Keskin DB, Allan DS, Rybalov B, Andzelm MM, Stern JN, Kopcow HD, Koopman LA \& Strominger JL 2007 TGF $\beta$ promotes conversion of $\mathrm{CD} 16^{+}$peripheral blood NK cells into $\mathrm{CD} 16^{-} \mathrm{NK}$ cells with similarities to decidual NK cells. PNAS 104 3378-3383. (doi:10.1073/pnas. 0611098104)

Kooh SW \& Vieth R 1980 25-hydroxyvitamin D metabolism in the sheep fetus and lamb. Pediatric Research 14 360-363. (doi:10.1203/00006450198004000-00022)

Kopcow HD, Eriksson M, Mselle TF, Damrauer SM, Wira CR, Sentman CL \& Strominger JL 2010 Human decidual NK cells from gravid uteri and NK cells from cycling endometrium are distinct NK cell subsets. Placenta $\mathbf{3 1}$ 334-338. (doi:10.1016/j.placenta.2010.01.003)

Korn T, Oukka M, Kuchroo V \& Bettelli E 2007 Th17 cells: effector T cells with inflammatory properties. Seminars in Immunology 19 362-371. (doi:10.1016/j.smim.2007.10.007)

Kovacs CS \& Kronenberg HM 1997 Maternal-fetal calcium and bone metabolism during pregnancy, puerperium, and lactation. Endocrine Reviews 18 832-872. (doi:10.1210/edrv.18.6.0319)

Kovacs CS, Woodland ML, Fudge NJ \& Friel JK 2005 The vitamin D receptor is not required for fetal mineral homeostasis or for the regulation of placental calcium transfer in mice. American Journal of Physiology. Endocrinology and Metabolism 289 E133-E144. (doi:10.1152/ajpendo. $00354.2004)$

Kreutz M, Andreesen R, Krause SW, Szabo A, Ritz E \& Reichel H 1993 1,25-dihydroxyvitamin D3 production and vitamin D3 receptor expression are developmentally regulated during differentiation of human monocytes into macrophages. Blood 82 1300-1307.

Kwan M, Hazan A, Zhang J, Jones R, Harris L, Whittle W, Keating S, Dunk C \& Lye S 2014 Dynamic changes in maternal decidual leukocyte populations from first to second trimester gestation. Placenta $\mathbf{3 5}$ 127-134. (doi:10.1016/j.placenta.2014.09.018)

Laird SM, Tuckerman EM, Cork BA, Linjawi S, Blakemore AI \& Li TC 2003 A review of immune cells and molecules in women with recurrent miscarriage. Human Reproduction Update 9 163-174. (doi:10.1093/ humupd/dmg013)

Lash GE, Robson SC \& Bulmer JN 2010a Review: Functional role of uterine natural killer (uNK) cells in human early pregnancy decidua. Placenta 31(Suppl) S87-S92. (doi:10.1016/j.placenta.2009.12.022)

Lash GE, Otun HA, Innes BA, Percival K, Searle RF, Robson SC \& Bulmer JN $2010 b$ Regulation of extravillous trophoblast invasion by uterine natural killer cells is dependent on gestational age. Human Reproduction 25 1137-1145. (doi:10.1093/humrep/deq050)

Laskarin G, Kammerer U, Rukavina D, Thomson AW, Fernandez N \& Blois SM 2007 Antigen-presenting cells and materno-fetal tolerance: an emerging role for dendritic cells. American Journal of Reproductive Immunology 58 255-267. (doi:10.1111/j.1600-0897.2007.00511.x)

Lemire JM, Archer DC, Beck L \& Spiegelberg HL 1995 Immunosuppressive actions of 1,25-dihydroxyvitamin D3: preferential inhibition of Th1 functions. Journal of Nutrition 125 1704S-1708S.

Leung KH 1989 Inhibition of human natural killer cell and lymphokineactivated killer cell cytotoxicity and differentiation by vitamin D3.
Scandinavian Journal of Immunology 30 199-208. (doi:10.1111/j.13653083.1989.tb01202.x)

Liu PT, Stenger S, Li H, Wenzel L, Tan BH, Krutzik SR, Ochoa MT, Schauber J, Wu K, Meinken C et al. 2006 Toll-like receptor triggering of a vitamin D-mediated human antimicrobial response. Science 311 1770-1773. (doi:10.1126/science.1123933)

Liu N, Nguyen L, Chun RF, Lagishetty V, Ren S, Wu S, Hollis B, DeLuca HF, Adams JS \& Hewison M 2008 Altered endocrine and autocrine metabolism of vitamin $\mathrm{D}$ in a mouse model of gastrointestinal inflammation. Endocrinology 149 4799-4808. (doi:10.1210/en.20080060)

Liu PT, Schenk M, Walker VP, Dempsey PW, Kanchanapoomi M, Wheelwright M, Vazirnia A, Zhang X, Steinmeyer A, Zugel U et al. 2009 Convergence of IL-1 $\beta$ and VDR activation pathways in human TLR2/1induced antimicrobial responses. PLoS ONE 4 e5810. (doi:10.1371/ journal.pone.0005810)

Liu NQ, Kaplan AT, Lagishetty V, Ouyang YB, Ouyang Y, Simmons CF, Equils $\mathrm{O} \&$ Hewison M 2011 Vitamin D and the regulation of placental inflammation. Journal of Immunology 186 5968-5974. (doi:10.4049/ jimmunol.1003332)

Liu NQ, Ouyang Y, Bulut Y, Lagishetty V, Chan SY, Hollis BW, Wagner C, Equils O \& Hewison M 2013 Dietary vitamin D restriction in pregnant female mice is associated with maternal hypertension and altered placental and fetal development. Endocrinology 154 2270-2280. (doi:10.1210/en.2012-2270)

Looker AC, Johnson CL, Lacher DA, Pfeiffer CM, Schleicher RL \& Sempos CT 2011 Vitamin D status: United States, 2001-2006. NCHS Data Brief $1-8$.

Lund B \& Selnes A 1979 Plasma 1,25-dihydroxyvitamin D levels in pregnancy and lactation. Acta Endocrinologica 92 330-335. (doi:10. 1530/acta.0.0920330)

Lynch L, Golden-Mason L, Eogan M, O'Herlihy C \& O'Farrelly C 2007 Cells with haematopoietic stem cell phenotype in adult human endometrium: relevance to infertility? Human Reproduction 22 919-926. (doi:10.1093/humrep/del456)

Male V, Hughes T, McClory S, Colucci F, Caligiuri MA \& Moffett A 2010 Immature NK cells, capable of producing IL-22, are present in human uterine mucosa. Journal of Immunology 185 3913-3918. (doi:10.4049/ jimmunol.1001637)

Mathieu C \& Badenhoop K 2005 Vitamin D and type 1 diabetes mellitus: state of the art. Trends in Endocrinology and Metabolism 16 261-266. (doi:10.1016/j.tem.2005.06.004)

Matsushita T, Yanaba K, Bouaziz JD, Fujimoto M \& Tedder TF 2008 Regulatory B cells inhibit EAE initiation in mice while other B cells promote disease progression. Journal of Clinical Investigation 118 3420-3430. (doi:10.1172/JCI36030)

Mehta S, Hunter DJ, Mugusi FM, Spiegelman D, Manji KP, Giovannucci EL, Hertzmark E, Msamanga GI \& Fawzi WW 2009 Perinatal outcomes, including mother-to-child transmission of HIV, and child mortality and their association with maternal vitamin D status in Tanzania. Journal of Infectious Diseases 200 1022-1030. (doi:10.1086/605699)

Merino F, Alvarez-Mon M, de la Hera A, Ales JE, Bonilla F \& Durantez A 1989 Regulation of natural killer cytotoxicity by 1,25 -dihydroxyvitamin D3. Cellular Immunology 118 328-336. (doi:10.1016/00088749(89)90381-X)

Mithal A, Wahl DA, Bonjour JP, Burckhardt P, Dawson-Hughes B, Eisman JA, El-Hajj Fuleihan G, Josse RG, Lips P \& Morales-Torres J 2009 Global vitamin $\mathrm{D}$ status and determinants of hypovitaminosis D. Osteoporosis International 20 1807-1820. (doi:10.1007/s00198-009-0954-6)

Moffett A \& Loke C 2006 Implantation, embryo-maternal interactions, immunology and modulation of the uterine environment - a workshop report. Placenta 27 S54-S55. (doi:10.1016/j.placenta.2006.01.021)

Moran-Auth Y, Penna-Martinez M, Shoghi F, Ramos-Lopez E \& Badenhoop K 2013 Vitamin D status and gene transcription in immune cells. Journal of Steroid Biochemistry and Molecular Biology 136 83-85. (doi:10.1016/j.jsbmb.2013.02.005) http://joe.endocrinology-journals.org DOI: 10.1530/JOE-14-0642
() 2015 Society for Endocrinology Printed in Great Britain 
Mosser DM 2003 The many faces of macrophage activation. Journal of Leukocyte Biology 73 209-212. (doi:10.1189/jlb.0602325)

Munger KL, Levin LI, Hollis BW, Howard NS \& Ascherio A 2006 Serum 25-hydroxyvitamin D levels and risk of multiple sclerosis. Journal of the American Medical Association 296 2832-2838. (doi:10.1001/jama.296. 23.2832)

Murphy LC, Wild J, Stone GM \& Posen S 1980 The effect of estradiol on a 25-hydroxycholecalciferol binding protein in the uterus of the mouse. Steroids 35 1-8. (doi:10.1016/0039-128X(80)90106-3)

Nunn JD, Katz DR, Barker S, Fraher LJ, Hewison M, Hendy GN \& O’Riordan JL 1986 Regulation of human tonsillar T-cell proliferation by the active metabolite of vitamin D3. Immunology 59 479-484.

O'Kelly J, Hisatake J, Hisatake Y, Bishop J, Norman A \& Koeffler HP 2002 Normal myelopoiesis but abnormal T lymphocyte responses in vitamin D receptor knockout mice. Journal of Clinical Investigation 109 1091-1099. (doi:10.1172/JCI0212392)

Ooi JH, McDaniel KL, Weaver V \& Cantorna MT 2014 Murine CD8 ${ }^{+}$T cells but not macrophages express the vitamin D $1 \alpha$-hydroxylase. Journal of Nutritional Biochemistry 25 58-65. (doi:10.1016/j.jnutbio.2013.09.003)

Oreshkova T, Dimitrov R \& Mourdjeva M 2012 A cross-talk of decidual stromal cells, trophoblast, and immune cells: a prerequisite for the success of pregnancy. American Journal of Reproductive Immunology $\mathbf{6 8}$ 366-373. (doi:10.1111/j.1600-0897.2012.01165.x)

Overbergh L, Decallonne B, Waer M, Rutgeerts O, Valckx D, Casteels KM, Laureys J, Bouillon R \& Mathieu C 2000 1 $\alpha$,25-dihydroxyvitamin D3 induces an autoantigen-specific T-helper 1/T-helper 2 immune shift in NOD mice immunized with GAD65 (p524-543). Diabetes 49 1301-1307. (doi:10.2337/diabetes.49.8.1301)

Pace D, Morrison L \& Bulmer JN 1989 Proliferative activity in endometrial stromal granulocytes throughout menstrual cycle and early pregnancy. Journal of Clinical Pathology 42 35-39. (doi:10.1136/jcp.42.1.35)

Palmer MT, Lee YK, Maynard CL, Oliver JR, Bikle DD, Jetten AM \& Weaver CT 2010 Lineage-specific effects of 1,25-dihydroxyvitamin $\mathrm{D}(3)$ on the development of effector CD4 T cells. Journal of Biological Chemistry 286 997-1004. (doi:10.1074/jbc.M110.163790)

Piccinni MP, Beloni L, Livi C, Maggi E, Scarselli G \& Romagnani S 1998 Defective production of both leukemia inhibitory factor and type 2 T-helper cytokines by decidual $\mathrm{T}$ cells in unexplained recurrent abortions. Nature Medicine 4 1020-1024. (doi:10.1038/2006)

Provvedini DM \& Manolagas SC 1989 1 $\alpha$,25-dihydroxyvitamin D3 receptor distribution and effects in subpopulations of normal human $\mathrm{T}$ lymphocytes. Journal of Clinical Endocrinology and Metabolism 68 774-779. (doi:10.1210/jcem-68-4-774)

Provvedini DM, Tsoukas CD, Deftos LJ \& Manolagas SC 1986 1 $\alpha, 25-$ Dihydroxyvitamin D3-binding macromolecules in human B lymphocytes: effects on immunoglobulin production. Journal of Immunology 136 2734-2740.

Public Health England and Food Standards Agency 2014. National Diet and Nutrition Survey. Headline results from Years 1, 2 and 3 (combined) of the Rolling Programme (2008/2009-2010/11). https://www.gov.uk.

Quenby S \& Farquharson R 2006 Uterine natural killer cells, implantation failure and recurrent miscarriage. Reproductive Biomedicine Online 13 24-28. (doi:10.1016/S1472-6483(10)62012-3)

Ramathal CY, Bagchi IC, Taylor RN \& Bagchi MK 2010 Endometrial decidualization: of mice and men. Seminars in Reproductive Medicine $\mathbf{2 8}$ 17-26. (doi:10.1055/s-0029-1242989)

Reichrath J \& Querings K 2005 Vitamin D deficiency during pregnancy: a risk factor not only for fetal growth and bone metabolism but also for correct development of the fetal immune system? American Journal of Clinical Nutrition 811177 author reply 1177-1178.

Rieger L, Honig A, Sutterlin M, Kapp M, Dietl J, Ruck P \& Kammerer U 2004 Antigen-presenting cells in human endometrium during the menstrual cycle compared to early pregnancy. Journal of the Society for Gynecologic Investigation 11 488-493. (doi:10.1016/j.jsgi.2004.05.007)

Rieger L, Segerer S, Bernar T, Kapp M, Majic M, Morr AK, Dietl J \& Kammerer U 2009 Specific subsets of immune cells in human decidua differ between normal pregnancy and preeclampsia - a prospective observational study. Reproductive Biology and Endocrinology 7132. (doi:10.1186/1477-7827-7-132)

Robson A, Harris LK, Innes BA, Lash GE, Aljunaidy MM, Aplin JD, Baker PN, Robson SC \& Bulmer JN 2012 Uterine natural killer cells initiate spiral artery remodeling in human pregnancy. FASEB Journal 26 4876-4885. (doi:10.1096/fj.12-210310)

Romagnani S 2006 Regulation of the T cell response. Clinical and Experimental Allergy 36 1357-1366. (doi:10.1111/j.1365-2222.2006. 02606.x)

Saito S, Umekage H, Sakamoto Y, Sakai M, Tanebe K, Sasaki Y \& Morikawa H 1999 Increased T-helper-1-type immunity and decreased T-helper2-type immunity in patients with preeclampsia. American Journal of Reproductive Immunology 41 297-306. (doi:10.1111/j.1600-0897.1999. tb00442.x)

Saito S, Nakashima A, Shima T \& Ito M 2010 Th1/Th2/Th17 and regulatory T-cell paradigm in pregnancy. American Journal of Reproductive Immunology 63 601-610. (doi:10.1111/j.1600-0897.2010.00852.x)

Salamonsen LA, Hannan NJ \& Dimitriadis E 2007 Cytokines and chemokines during human embryo implantation: roles in implantation and early placentation. Seminars in Reproductive Medicine $\mathbf{2 5}$ 437-444. (doi:10.1055/s-2007-991041)

Scaife P, Searle R, Robson S, Innes B \& Bulmer J 2003 A comparison of cytotoxic decidual leukocyte populations in early and late pregnancy. Journal of the Society for Gynecologic Investigation 10360 A.

Schonkeren D, van der Hoorn ML, Khedoe P, Swings G, van Beelen E, Claas F, van Kooten C, de Heer E \& Scherjon S 2011 Differential distribution and phenotype of decidual macrophages in preeclamptic versus control pregnancies. American Journal of Pathology 178 709-717. (doi:10.1016/ j.ajpath.2010.10.011)

Shin DM, Yuk JM, Lee HM, Lee SH, Son JW, Harding CV, Kim JM, Modlin RL \& Jo EK 2011 Mycobacterial lipoprotein activates autophagy via TLR2/1/CD14 and a functional vitamin D receptor signalling. Cellular Microbiology 12 1648-1665. (doi:10.1111/j.1462-5822.2010.01497.x)

Shiozawa K, Shiozawa S, Shimizu S \& Fujita T 1985 1 $\alpha$,25-dihydroxyvitamin D3 inhibits pokeweed mitogen-stimulated human B-cell activation: an analysis using serum-free culture conditions. Immunology 56 161-167.

Spach KM, Nashold FE, Dittel BN \& Hayes CE 2006 IL-10 signaling is essential for 1,25-dihydroxyvitamin D3-mediated inhibition of experimental autoimmune encephalomyelitis. Journal of Immunology 177 6030-6037. (doi:10.4049/jimmunol.177.9.6030)

Takeda K \& Akira S 2005 Toll-like receptors in innate immunity. International Immunology 17 1-14. (doi:10.1093/intimm/dxh186)

Trundley A \& Moffett A 2004 Human uterine leukocytes and pregnancy. Tissue Antigens 63 1-12. (doi:10.1111/j.1399-0039.2004.00170.x)

Turner M, Barre PE, Benjamin A, Goltzman D \& Gascon-Barre M 1988 Does the maternal kidney contribute to the increased circulating 1,25-dihydroxyvitamin D concentrations during pregnancy? Mineral and Electrolyte Metabolism 14 246-252.

Urrutia RP \& Thorp JM 2012 Vitamin D in pregnancy: current concepts. Current Opinion in Obstetrics \& Gynecology 24 57-64. (doi:10.1097/GCO. Ob013e3283505ab3)

Urry Z, Xystrakis E, Richards DF, McDonald J, Sattar Z, Cousins DJ, Corrigan CJ, Hickman E, Brown Z \& Hawrylowicz CM 2009 Ligation of TLR9 induced on human IL-10-secreting Tregs by $1 \alpha, 25$-dihydroxyvitamin D3 abrogates regulatory function. Journal of Clinical Investigation 119 387-398.

Vacca P, Moretta L, Moretta A \& Mingari MC 2011 Origin, phenotype and function of human natural killer cells in pregnancy. Trends in Immunology 32 517-523. (doi:10.1016/j.it.2011.06.013)

Van Cromphaut SJ, Rummens K, Stockmans I, Van Herck E, Dijcks FA, Ederveen AG, Carmeliet P, Verhaeghe J, Bouillon R \& Carmeliet G 2003 Intestinal calcium transporter genes are upregulated by estrogens and the reproductive cycle through vitamin D receptor-independent 
mechanisms. Journal of Bone and Mineral Research 18 1725-1736. (doi:10.1359/jbmr.2003.18.10.1725)

Wang TT, Nestel FP, Bourdeau V, Nagai Y, Wang Q, Liao J, Tavera-Mendoza L, Lin R, Hanrahan JW, Mader S et al. 2004 Cutting edge: 1,25dihydroxyvitamin D3 is a direct inducer of antimicrobial peptide gene expression. Journal of Immunology 173 2909-2912. (doi:10.4049/ jimmunol.173.5.2909)

Warning JC, McCracken SA \& Morris JM 2011 A balancing act: mechanisms by which the fetus avoids rejection by the maternal immune system. Reproduction 141 715-724. (doi:10.1530/ REP-10-0360)

Wegmann TG, Lin H, Guilbert L \& Mosmann TR 1993 Bidirectional cytokine interactions in the maternal-fetal relationship: is successful pregnancy a TH2 phenomenon? Immunology Today 14 353-356. (doi:10.1016/0167-5699(93)90235-D)

Weisman Y, Vargas A, Duckett G, Reiter E \& Root AW 1978 Synthesis of 1,25-dihydroxyvitamin $\mathrm{D}$ in the nephrectomized pregnant rat. Endocrinology 103 1992-1996. (doi:10.1210/endo-103-6-1992)

Weisman Y, Harell A, Edelstein S, David M, Spirer Z \& Golander A 1979 1 $\alpha, 25$-Dihydroxyvitamin D3 and 24,25-dihydroxyvitamin D3 in vitro synthesis by human decidua and placenta. Nature 281 317-319. (doi:10.1038/281317a0)

Willheim M, Thien R, Schrattbauer K, Bajna E, Holub M, Gruber R, Baier K, Pietschmann P, Reinisch W, Scheiner O et al. 1999 Regulatory effects of
1 $\alpha, 25$-dihydroxyvitamin D3 on the cytokine production of human peripheral blood lymphocytes. Journal of Clinical Endocrinology and Metabolism 84 3739-3744.

Williams PJ, Bulmer JN, Searle RF, Innes BA \& Robson SC 2009 Altered decidual leucocyte populations in the placental bed in pre-eclampsia and fetal growth restriction: a comparison with late normal pregnancy. Reproduction 138 177-184. (doi:10.1530/REP-09-0007)

Woodham PC, Brittain JE, Baker AM, Long DL, Haeri S, Camargo CA Jr, Boggess KA \& Stuebe AM 2011 Midgestation maternal serum 25hydroxyvitamin D level and soluble fms-like tyrosine kinase 1/ placental growth factor ratio as predictors of severe preeclampsia. Hypertension 58 1120-1125. (doi:10.1161/HYPERTENSIONAHA.111. 179069)

Yu S \& Cantorna MT 2011 Epigenetic reduction in invariant NKT cells following in utero vitamin D deficiency in mice. Journal of Immunology 186 1384-1390. (doi:10.4049/jimmunol.1002545)

Zehnder D, Evans KN, Kilby MD, Bulmer JN, Innes BA, Stewart PM \& Hewison M 2002 The ontogeny of 25-hydroxyvitamin D(3) $1 \alpha$-hydroxylase expression in human placenta and decidua. American Journal of Pathology 161 105-114. (doi:10.1016/S00029440(10)64162-4)

Zittermann A, Gummert JF \& Borgermann J 2011 The role of vitamin D in dyslipidemia and cardiovascular disease. Current Pharmaceutical Design 17 933-942. (doi:10.2174/138161211795428786)

Received in final form 4 December 2014

Accepted 15 December 2014
(C) 2015 Society for Endocrinology Printed in Great Britain 